\title{
Chapter 12 \\ The Significance of Foreign Labour \\ Migration and Land for Poverty \\ Reduction in Nepal
}

\section{Ramesh Sunam}

\begin{abstract}
Nepal has witnessed a decline in poverty in the last decade, although GDP growth is low and stagnant at around $4 \%$. What explains this decline is little researched. Descent poverty, or how some households tend to fall into poverty, is another important facet of poverty dynamics, which has also received little scholarly attention. This paper, therefore, examines pathways leading to poverty dynamics in rural Nepal. Employing the 'Stages of Progress' methodology, this paper shows that nearly one-third of the total 386 households studied have escaped poverty, while $7 \%$ have fallen into poverty over the last two decades. Foreign labour migration, small business and access to land define the movement of most households out of poverty, whereas loss of land, cultural burdens and health costs are the main factors associated with descent into poverty. This paper suggests two distinct sets of policies for promoting escape from poverty and for preventing descent into poverty. Such policies need to consider the situation of the poor who are unable to pursue labour migration, and the left behind household members, enabling their access to land and creating local employment.
\end{abstract}

Keywords Agriculture $\cdot$ Foreign migration $\cdot$ Land $\cdot$ Nepal $\cdot$ Poverty

\subsection{Introduction}

Economic growth is often considered as the pathway out of poverty as many crosscountry studies show that economic growth strongly correlates with poverty reduction. However, this relationship does not explain how it works out in a particular context. In Nepal, as in many developing countries, while GDP growth is low and stagnant at around $4 \%$ in the last decade, poverty in absolute terms has declined in the same

\footnotetext{
R. Sunam $(\bowtie)$

Crawford School of Public Policy, Australian National University, Canberra, Australia e-mail: rameshsunam@gmail.com
} 
period from 41.76 to $25.16 \%$ (ADB 2009; CBS 2011). An explanation of this decline in the Nepali context in terms of the rural people's own understanding is an area that has not been studied. Further, descent poverty — some households having the tendency to fall into poverty - is little understood. This dimension of poverty dynamics, 'becoming poor', is often neglected in research and the development discourse. Factors associated with escape differ from that attributed to descent (Barrett et al. 2006; Krishna et al. 2006). Even in a country witnessing an economic miracle, there might be a huge number of households slipping into poverty, alongside many households escape from the poverty trap (Ravallion 2001). Controlling households' decline into poverty is, thus, as important as promoting other households' escape from poverty.

Many studies, based on panel data, have examined poverty dynamics- the extent to which households fall into and escape from poverty. Some examples of such studies include the work by Lawson et al. (2006), Barrett et al. (2001), Christiaensen and Subbarao (2005), Davis and Baulch (2011), Moser and Felton (2007), and Quisumbing (2007). However, these studies put little emphasis on the factors and strategies that poor households utilise to deal with their impoverishment. Contrary to the wider assumption that poor households just wait for benefits from non-governmental organizations (NGOs) or the government to come their way, they rather try on their part to improve their status through different livelihood strategies. But there is a considerable gap in understanding the strategies and processes leading to poverty outcomes (Ellis 2000). For understanding factors and processes that drive mobility at the community and household levels, participatory research methods have been advocated. This study employs one such methodology — 'Stages of Progress' - developed by A. Krishna (2005) ${ }^{1}$ and later adapted with modification by other researchers for unravelling the factors associated with escaping from and falling into poverty.

Results are presented from fieldwork conducted in 11 hamlets from the Tarai region of Nepal between January 2012 and February 2013. Of the total of 386 households, $29.5 \%$ have escaped from poverty in the last 22 years, but $7 \%$ have also fallen into poverty during the same period, and these numbers vary considerably from hamlet to hamlet. One set of factors is linked with escape from poverty, while a different set of factors is associated with falling into poverty. It, thus, suggests that two different sets of public policies are required: one set to save households from falling into poverty and another set to help them escape from poverty. While foreign labour migration, farming and small businesses constitute major reasons for households escaping poverty, the most important reasons associated with the households' decline into poverty include loss of land, and cultural and social expenses.

\subsection{Methodology}

This paper draws on the fieldwork conducted in 11 hamlets, called Tole in a local language, from Sunsari district of the Tarai region, Nepal. Altogether 386 households are resident in these hamlets. The selected hamlets closely represent the

${ }^{1}$ http://www.sanford.duke.edu/krishna/index.html. 
considerable diversity that exists within the Tarai in terms of caste/indigenous peoples, economic activities and migration patterns since carefully selected and rich cases can potentially yield valid and useful findings (Flyvbjerg 2002). The economy of these hamlets is predominantly based on farming, although other non-farm income sources are increasingly available. Rice is the main cereal crop, but wheat, maize and potato are also grown.

This study has employed mixed research methods to enrich findings through creating 'synergy' between quantitative and qualitative techniques (White 2002). To examine poverty dynamics and identify factors associated with escaping poverty or otherwise, a community-based, participatory, retrospective methodology called 'Stages of Progress' has been employed (see Krishna 2010). This methodology has been advanced as an important tool for understanding rural poverty as opposed to imposing poverty indicators on local communities. As the residents in the selected hamlets are longstanding in close-knit communities, this methodology has been advocated for such cases. The suggested steps have been briefly described here since an extended illustration of this methodology can be found elsewhere (Krishna 2010; Kristjanson et al. 2010).

Step 1 Forming a representative community group. In each hamlet, a community group of five to seven people was assembled. This group consisted of members belonging to diverse social groups along caste, gender and age lines. It was ensured that at least three members belonged to older members of the community and/or were women since they are believed to be more knowledgeable about households' situations over a long period of time.

Step 2 Presenting the objectives of study. The objectives of the exercise were clarified to the community group. In addition, key issues were made clear which could act as sources for manipulating or misrepresenting their response. In this regard, it was informed that no benefits would be given to any participants or households under consideration and that no development program was in the offing.

Step 3 Defining what it means to be a poor household. This is the most crucial step because we identified the local understanding of poverty at a community meeting. We asked community groups to explore the stages of progress in terms of assets and capabilities that poor households pass through to move out of poverty. The following stages were identified after rigorous discussions at a community meeting (Table 12.1).

These first five stages reflect the local understanding of poverty. When a household has no worries about these stages, such a household is considered non-poor in the definition of the local people. The fifth stage is a socially constructed poverty cut-off, equivalent to poverty line (e.g. one dollar a day). A surprising agreement was reached among community groups for the first five stages, but it recedes when identifying the successive stages in the ladder of upward mobility. Each movement upward along the stages of progress represents a gradual improvement in the material and social status of households. 
Table 12.1 Stages of progress with poverty cut-off

\begin{tabular}{l|l|l}
\hline \multicolumn{2}{l}{ Stages of progress } & \\
\hline 1 & Food for the family & \\
\hline 2 & Some clothes for family while going to towns or social functions & \\
\hline 3 & Sending children to school & \\
\hline 4 & Repairing the existing shelter (roof with iron sheets) & $\begin{array}{l}\text { Poverty } \\
\text { cut-off }\end{array}$ \\
\hline 5 & Covering basic medical expenses
\end{tabular}

Step 4 Inquiring about households' poverty status today and 22 years ago. Community groups were then asked to categorise households in the present time and 22 years ago along the stages identified in the previous exercise. Before doing this, a complete list of all households in each hamlet was prepared. A reference point was made to a significant event-the reinstatement of democracy in Nepal in 1990 — which is easily and commonly remembered. This was a shared point for recounting the past.

Step 5 Assigning households to particular categories. After identifying the stages of households, we assigned each household into one of the following four categories:

\begin{tabular}{l|l}
\hline Category $A$ & Poor now and poor earlier (Remained poor) \\
\hline Category $B$ & Poor earlier, but not poor now (Escaped poverty) \\
\hline Category $C$ & Nor poor earlier, but poor now (Became poor); and \\
\hline Category $D$ & $\begin{array}{l}\text { Not poor earlier and not poor now (Remained } \\
\text { non-poor) }\end{array}$ \\
\hline
\end{tabular}

The unit of analysis is households of the present time, but in the case of households younger than 22 years old, we asked about the conditions in their parents' households.

Step 6 Inquiring about reasons for escape and reasons for descent with respect to a random sample of households. Approximately $40 \%$ of all households in each of the four categories were randomly chosen for eliciting the reasons behind escape and descent. The members of community groups were inquired about the reasons, processes and events (the causes and contributing factors) associated with each household's trajectory.

Step 7 Following up by interviewing household members. We surveyed 170 households drawn through random sampling to further collect information about their household trajectories and to cross-check the information provided by the community group. In the meantime, we collected basic socio-economic and demographic data such as landholding, education and asset ownership. For smoother data analysis, the reasons, processes and events recorded in each case were coded using a code sheet.

Prior to implementing this methodology, two research assistants who can speak local languages were recruited and trained. The principal researcher closely supervised the research assistants during the study period. 


\subsection{Poverty Trends: Moving Out, Moving In}

Results from the analysis of data obtained through the Stages of Progress methodology show that about $73.3 \%$ of the 386 households were poor 22 years ago and $50.8 \%$ are poor today (Table 12.2). Nearly one-third of total households have changed their status from being poor to non-poor over the last two decades. However, $43.8 \%$ of all households have remained poor, and in the meantime, $7 \%$ have slipped into poverty. The poverty escape rate is $29.5 \%$, while the decline rate is $7 \%$, showing a net improvement of $22.5 \%$.

The official figure for poverty (headcount) in Nepal is $25.16 \%$ (CBS 2011). Our estimate is doubly higher $(50.8 \%)$. Perhaps this higher figure is due to a large proportion of Dalits (the so called low-caste peoples) and indigenous peoples (both social groups are largely impoverished people across the country), who reside in the study area. Moreover, since the local definition of poverty as used here involves very basic needs such as food, clothing and shelter, those who are identified here as poor by community groups are unlikely to be non-poor in terms of any plausible criteria of poverty. We have also observed miserable conditions of many households during the fieldwork.

Now it is useful to see the relationship between the four categories and some other widely used indicators of poverty in the academic and policy discourse. In fact, other indicators also provide support to our poverty categories. Of those who have remained poor (Category $A$ ), $71 \%$ are landless and $47 \%$ are daily labourers. The average land ownership for this category is 0.10 bighas ( 1 bigha $=0.68$ ha). In contrast, average ownership for Category $D$ is 1.42 bighas; that is, households in this category possess more than fourteen times as much land as those in Category $A$. Average landownership for Category $B$ and Category $C$ is 0.36 and 0.40 , respectively (Table 12.3 ).

Livestock size also varies substantially between households identified as being poor and non-poor (see Table 12.4). Category $A$ households possess just 8.9 animals on an average, while Category $D$ households own almost double (17.2 animals).

Ownership of other assets is also similarly distributed along these four poverty categories as shown in Table 12.5. Households were asked about ownership of five types of assets—radio, TV, mobile, bicycle and motorbike. On an average,

Table 12.2 Trends in household poverty (poor households $\%, n=386$ )

\begin{tabular}{l|l|l}
\hline \multirow{2}{*}{ At present } & 22 years ago & \\
\cline { 2 - 3 } & Poor & Not poor \\
\hline \multirow{2}{*}{ Poor } & $43.8 \%$ & $7 \%$ \\
\cline { 2 - 3 } & Remained poor $(A)$ & Became poor $(C)$ \\
\hline \multirow{2}{*}{ Not poor } & $29.5 \%$ & $19.7 \%$ \\
\cline { 2 - 3 } & Escaped poverty $(B)$ & Remained non-poor $(D)$ \\
\hline
\end{tabular}

Poor today $(A+C)=50.8 \%$

Poor 22 years ago $(A+B)=73.3 \%$ 
Table 12.3 Land-related parameters and poverty

\begin{tabular}{l|l|l|l|l}
\hline & $\begin{array}{l}\text { Remained } \\
\text { poor }(A)\end{array}$ & $\begin{array}{l}\text { Escaped poverty } \\
(B)\end{array}$ & $\begin{array}{l}\text { Became } \\
\text { poor }(C)\end{array}$ & Remained non-poor $(D)$ \\
\hline $\begin{array}{l}\text { Landownership (in } \\
\text { bigha }^{\mathrm{a}} \text { ) }\end{array}$ & 0.10 & 0.36 & 0.40 & 1.42 \\
\hline $\begin{array}{l}\text { Rented in (\% of house- } \\
\text { holds in each category) }\end{array}$ & 47 & 35 & 36 & 18 \\
\hline $\begin{array}{l}\text { Rented out (\% of } \\
\text { households in each } \\
\text { category) }\end{array}$ & 0 & 3 & 0 & 20 \\
\hline
\end{tabular}

${ }^{\mathrm{a}} 1$ bigha $=0.68$ ha

Table 12.4 Livestock possession and poverty

\begin{tabular}{l|l|l|l|l}
\hline \multirow{2}{*}{$\begin{array}{l}\text { Type of } \\
\text { animals }\end{array}$} & \multicolumn{4}{|l}{ Animal possession for each category (average) } \\
\cline { 2 - 5 } & $\begin{array}{l}\text { Remained poor } \\
(A)\end{array}$ & $\begin{array}{l}\text { Escaped poverty } \\
(B)\end{array}$ & $\begin{array}{l}\text { Became poor } \\
(C)\end{array}$ & $\begin{array}{l}\text { Remained non-poor } \\
(D)\end{array}$ \\
\hline Cattle & 1.4 & 2.1 & 1.5 & 2.2 \\
\hline Buffalo & 0.3 & 0.3 & 0.2 & 0.6 \\
\hline Goats & 1.8 & 2.4 & 1.9 & 2.6 \\
\hline Pigs & 0.1 & 0.5 & 0.2 & 0.7 \\
\hline Chicken & 3.3 & 5.4 & 1.7 & 9.1 \\
\hline Ducks & 1.9 & 1.9 & 3.0 & 2.1 \\
\hline Total & 8.9 & 12.6 & 8.5 & 17.2 \\
\hline
\end{tabular}

Table 12.5 Asset possession and poverty

\begin{tabular}{l|l|l|l|l}
\hline \multirow{2}{*}{$\begin{array}{l}\text { Type of } \\
\text { asset }\end{array}$} & \multicolumn{4}{|l}{ Asset possession for each category (average) } \\
\cline { 2 - 5 } & $\begin{array}{l}\text { Remained poor } \\
(A)\end{array}$ & $\begin{array}{l}\text { Escaped poverty } \\
(B)\end{array}$ & $\begin{array}{l}\text { Became poor } \\
(C)\end{array}$ & $\begin{array}{l}\text { Remained non-poor } \\
(D)\end{array}$ \\
\hline Radio & 0.3 & 0.5 & 0.4 & 0.6 \\
\hline TV & 0.4 & 0.9 & 0.5 & 0.9 \\
\hline Mobile & 1.0 & 1.9 & 1.5 & 1.9 \\
\hline Bicycle & 0.8 & 1.1 & 0.9 & 1.1 \\
\hline Motorbike & 0.1 & 0.2 & 0.0 & 0.1 \\
\hline Total & 2.7 & 4.7 & 3.2 & 4.5 \\
\hline
\end{tabular}

households of Category $A$ (remained poor) possess 2.7 of these five assets, while households of Category $D$ (remained non-poor) possess nearly double (4.5).

To sum up, households identified as poor through the Stages of Progress methodology are equally poor, in terms of other indicators of relative wealth relevant to rural agrarian context. Next section identifies and explains common 
reasons associated with households moving out and moving into poverty, the prime focus of this paper.

\subsection{Explaining the Movement of People in and Out of Poverty}

This section explains factors that are associated with households moving out and staying in poverty. Initially, community groups - the key informants-were asked about reasons behind the movement of households and the responses obtained were then verified and complemented through household interviews in a randomly selected sample of $40 \%$ of the total households.

\subsubsection{Pathways Out of Poverty}

Of the total 386 households, $29.5 \%$ have escaped poverty in the last two decades. Not a single factor is telling in explaining this movement of households out of poverty in the study area. Rather, different factors seem to be working alone or in combination (Table 12.6). Temporary labour migration of households abroad is the first major reason behind escape. About $60 \%$ of the households that became non-poor over the last 22 years reported that they could utilise labour migration opportunities to the Gulf countries such as Qatar, UAE, and Saudi Arabia and to Malaysia for improving their livelihoods. During the interviews, the poor households said that they have utilised remittances received from foreign migration in buying food, clothes and land, and repairing or building new houses. They have also been able to afford their children's education to private schools, where the quality of education is perceived to be better than in public schools. Importantly, foreign labour migration is different from seasonal or rural-urban migration in which migrants leave home for some months during the lean season and return

Table 12.6 Principal reasons for escaping poverty $(n=114)$

\begin{tabular}{l|l}
\hline Reasons & \% of poverty escaping households \\
\hline Foreign labour migration & 60 \\
\hline Own farming & 22 \\
\hline Sharecropping & 42 \\
\hline Small business & 41 \\
\hline Government job & 21 \\
\hline Private job including labouring & 25
\end{tabular}

Note The numbers in each column add up to more than 100 because multiple causes are usually associated with each case 
home when farming season starts. But foreign labour migration, in which migrants spend a longer period, usually more than a year, away from their home country can potentially remit more money than seasonal migrants (De Haas 2005).

In the recent years, foreign labour migration has been quite phenomenal and on a dramatic rise in Nepal. Nepal is one of the largest labour-sending countries (Poertner et al. 2011). Across Nepal, about one-third of total households have at least one family member abroad, and over $55.8 \%$ households receive remittances (CBS 2011), which amount to about $22 \%$ of the total GDP of the country (GON 2011). As foreign migration has been considered in analysing poverty for Nepal, some studies have attributed poverty reduction to remittances from both internal and international migration (Lokshin et al. 2007). However, this factor-migration-has not been discussed in similar studies conducted in India, although the importance of rural-urban migration for poor households even in India, particularly for lower castes and adivasi (tribal peoples), has been widely cited (Mosse et al. 2005).

Farming is another important factor for rural households to reduce their poverty. Some households have worked their own land, while others have rented in land on a sharecropping basis, a kind of tenancy where the cultivator provides half of the grains to the land owner. Some $35 \%$ of the households that escaped poverty have rented in land for tenancy. Basically, farming or sharecropping alone has not worked to lift the poor out of poverty. However, it provides subsistence living, a basis for upward mobility, as the poverty escaped households reported. Then, these households can accumulate some money earned from wage labouring or migration. So access to land is important. The households that remained in poverty are mostly those without land ownership or no access to land. This finding, therefore, does not support the argument that land is no longer important as a pathway out of rural poverty (Rigg 2006). Access to land on virtuous terms still defines the movement of poor households out of impoverishment. The importance of the land tenure system for economic performance has been well analysed by Banerjee and Iyer (2005) in the context of India.

Not only farming but also small business has helped rural households to fight poverty. Small business includes local kiosks, local bars, groceries, bottle shops, dairy, and poultry. Land is necessary for operating some business such as dairy, swine/pig farming and goat keeping. Similarly, about $21 \%$ of the poverty escaped households mentioned that government jobs-permanent salaried jobs-constitute a key factor in crushing their impoverishment. However, only one-fifth of total households have been able to access government jobs. In addition, those who are in the government jobs are from high-caste households, while very few indigenous and Dalit households hold such jobs. This relates to historical discrimination and injustice inflicted upon these backward castes by the state.

As indicated earlier, labouring opportunities beyond farming have also been increasingly important for rural households. In the study sites, $25 \%$ of the households that escaped poverty gave credit to wage labouring. Labouring opportunities may be available in construction activities or in local industries at local towns. What is disappointing here is that although this part of Nepal has many industries, 
Table 12.7 Results of binary logistic regression for escaping from poverty

\begin{tabular}{l|l|l}
\hline & Odds ratio & $95 \%$ confidence interval \\
\hline Intercept & 0.12 & \\
\hline Foreign migration & $3.83^{\mathrm{b}}$ & $1.96-7.51$ \\
\hline Farming & 4.06 & $1.20-13.66$ \\
\hline Sharecropping & 1.22 & $0.60-2.55$ \\
\hline Agribusiness gain & $3.27^{\mathrm{a}}$ & $1.31-8.15$ \\
\hline Diversification of incomes & 1.73 & $0.62-4.83$ \\
\hline Dalit caste & 0.51 & $0.08-3.19$ \\
\hline Labouring & 0.23 & $0.06-0.97$ \\
\hline Land & $3.33^{\mathrm{b}}$ & $1.69-6.58$ \\
\hline Log likelihood & -123.22 & \\
\hline Likelihood ratio Chi-square & 135.11 & \\
\hline Pr $>$ Chi-square & 0.0000 & \\
\hline$N$ & 283 & \\
\hline
\end{tabular}

Notes The population considered in this model is households who were poor in the earlier period (i.e. Category $A$ and Category $B$ households). The dependent variable is specified as escaping from poverty $=1$

${ }^{a}$ Statistically significant at 0.05 level

${ }^{\mathrm{b}}$ Statistically significant at 0.01 level

very few households have got employment. Instead, there have been cases of labourers being abused by petty contractors. It seems that industrial growth has not always produced jobs in numbers large enough to make a significant dent in poverty.

Table 12.7 reports the results from logistic regression that compare the experiences of households that escape poverty and that remain in poverty. The focus is to investigate why some poor households became non-poor, while other households remained poor. Results indicate that the likelihood of becoming nonpoor is substantially higher for households that are involved in foreign labour migration, run businesses or own some land. The odds of a poor household escaping poverty increase by a factor of 3.83 in cases where a household member is engaged in foreign migration, and by 3.33 times and 3.27 times in cases where households owned some land and pursued agriculture related business, respectively.

\subsubsection{Pathways Leading into Poverty}

About $7 \%$ of total households have fallen into poverty in the study area. Even some well off households have become impoverished in the last two decades. Health-related causes are important reasons for falling into poverty. These reasons were reported as important factors in some $20 \%$ of all households that have 
Table 12.8 Principal reasons for falling into poverty

\begin{tabular}{l|l}
\hline Reasons & \% of households falling into poverty \\
\hline Poor health and health-related expenses & 19 \\
\hline Cultural costs (marriage, dowry, death rituals) & 48 \\
\hline Land loss & 62 \\
\hline Others (alcoholism, laziness, etc.) & 28 \\
\hline
\end{tabular}

Note The numbers in each column add up to more than 100 because multiple causes are usually associated with each case

slipped into poverty (see Table 12.8). Ill health and the medical expenses constitute health causes.

Social and cultural expenses represent a dominant factor, and nearly half of the households that fell into poverty reported it. Such costs entail costs associated with marriage ceremonies, dowries, feasts and death rituals. A huge amount of expenditure is made for these events. Although these events do not occur every year, they tend to absorb a huge sum of money, according to the accounts of many households that were surveyed. In some cases, they even result in indebtedness. Indigenous peoples, Tharus, organise lavish parties during weddings and also offer dowries - a social obligation and a matter of prestige in the village. Some households have become landless because they sold their land to cover costs of their daughters' weddings and dowries. Social reform movements will require attention for addressing such causes.

Land loss constitutes another dominant factor associated with pushing a large number of households into poverty. About $60 \%$ of the households cited loss of their land as a reason for their fall into enervating poverty. Apart from social and cultural reasons of losing land, some households have also sold land to cover their basic living expenses and costs associated with foreign migration. When they fail to earn sizable remittances through foreign migration, some households have plunged into poverty. So households may even fall into poverty due to migration processes if they fail to generate remittances in the end.

Unlike the findings of Krishna (2006), debt burden is not an important factor in this case. Very few poor households cite debt as an important reason for falling into poverty. A handful of reasons may explain this. First, poor households who have migrated aspired to repay debt from remittances. Among those who have not migrated, most of them do not take loans, instead relying on daily labouring to cover the costs of living. Another reason could be that farming is just subsistenceoriented in the study area, so farmers do not intend to purchase fertilisers and pesticides which could have otherwise rendered them indebted. On the contrary, in many parts of India, commercial farming is likely to squeeze farmers into immiseration. This could be a reason that studies from India have indicated agricultural debt as a major factor.

The results of logistic regression presented in Table 12.9 further confirm these findings. Here, the main focus is to examine why some previously non-poor households became poor, while other non-poor households have maintained their 
Table 12.9 Results of binary logistic regression for falling into poverty

\begin{tabular}{l|l|l}
\hline & Odds ratio & $95 \%$ confidence Interval \\
\hline Intercept & 2.21 & \\
\hline Ill health & 0.94 & $0.07-12.71$ \\
\hline Marriage and other social expenses & $1.14^{\mathrm{a}}$ & $0.01-2.0$ \\
\hline Alcohol & 2.36 & $0.23-23.53$ \\
\hline Land loss & $21.70^{\mathrm{a}}$ & $1.53-307.07$ \\
\hline Foreign migration & 0.10 & $0.01-1.03$ \\
\hline Farming & 0.01 & $0.00-0.21$ \\
\hline Government job & 0.12 & $0.00-2.30$ \\
\hline Diversification of income sources & 0.21 & $0.03-1.43$ \\
\hline Indigenous peoples & 3.47 & $0.48-24.70$ \\
\hline Log likelihood & -21.06 & \\
\hline Likelihood ratio Chi-square & 76.37 & \\
\hline Pr $>$ Chi-square & 0.0000 & \\
\hline$N$ & 103 & \\
\hline$N$
\end{tabular}

Notes The population considered in this model is households who were not poor in the earlier period (i.e. Category $C$ and Category $D$ households). The dependent variable is specified as falling into poverty $=1$

${ }^{\text {a }}$ Statistically significant at 0.05 level

status as non-poor. As seen in Table 12.9, mainly two factors, namely loss of land, and marriage and social expenses are significantly associated with falling into poverty. For variables that are significant, an odds ratio greater than one indicates that the related factor tends to accelerate descent, while an odds ratio lower than 1 indicates that the related factor tends to control descents into poverty. For instance, the odds ratios of land loss, and marriage and other social expenses are 21.70 and 1.14 , respectively, implying that the odds of falling into poverty were enhanced by roughly 20 times and 1.14 times for households that have lost land and made marriage and other social expenses.

\subsection{Conclusion: Connecting Pathways Out of Poverty}

This paper has examined rural poverty dynamics in the Tarai region of Nepal to identify the extent of households moving in and out of poverty and the reasons associated with the mobility. The methodology employed here-the Stages of Progress-is useful for understanding poverty in the poor people's own terms. In the study area, community groups used local poverty indicators for dividing households into different categories: remained poor, poverty escaped, fell into poverty and remained non-poor. These categories of households were then verified by the data about the possession of different assets, including land and livestock, collected through the household surveys. The possession of different assets also 
confirmed the reliability of poverty categories. Such an asset-based approach to poverty measurement has several advantages over income-based measures (Carter and Barrett 2006). Barrett et al. (2006) offer empirical evidence that household welfare dynamics differ significantly as to whether an asset-based measure or an income-based welfare measure is used.

The results from this study reveal that over a period of 22 years, about $29.5 \%$ of the total households escaped poverty, while $7 \%$ fell into poverty. So the net improvement was about $22 \%$. A multitude of factors are associated with the mobility of households. However, the factors associated with escape from poverty differ from those associated with falling into poverty.

Major reasons behind escaping from poverty constitute foreign labour migration, farming, holding government jobs and small businesses. These different routes out of poverty are not a surprise since rural households in developing countries are engaged in multiple activities to improve their livelihoods (Ellis 2000). As the results suggest, the majority of households have pursued outmigration as a strategy to escape poverty. Increased foreign labour migration can be attributed to poor economic growth and the limited availability of job opportunities in the country. Further, the availability of land for farming has diminished because of an increasing population and other alternative land uses. Incomes from the traditional peasant mode of farming have been inadequate for rural households to improve their social and economic status (Adhikari and Hobley 2011). For these reasons, across the country, the trend of outmigration has seen a dramatic rise and over $55 \%$ of the total households receive remittances according to the recent national survey (CBS 2011).

Not many households can access government jobs nor is it feasible for the government to create additional government jobs for all poor people. So this cannot be suggested as a plausible pathway out of poverty. The remaining routes mostly echo the three main pathways-identified by the World Bank in its flagship annual report of 2008 - that lift rural households out of poverty, namely commercial farming, labour and migration (World Bank 2008). How these pathways can be accessible to the poor on favourable terms largely determine the likelihood of them exiting from poverty.

Although commercial farming has not taken roots in the study area, subsistence farming has provided a basis for households to move upward because it provides food and also creates an opportunity for them to save earnings from other non-farm activities such as labouring and migration. This suggests that no single route-farming, migration or labouring — has been effective for poverty reduction. Many households merely continuing traditional agriculture, migration or just labouring have been stuck in stagnation. The households combining these activities-for instance, a household being engaged in both farming and foreign migration-have been found to have escaped poverty. In other words, diversification of income sources has been a key factor for the vast majority of households in improving their livelihoods.

This finding is consistent with a number of similar studies. In Tanzania, the farmers who diversified livelihood activities_-growing staple foods for own use in 
addition to farming cash crops and rearing livestock-were found to be successful in breaking poverty traps (De Weerdt 2006). In Uganda, many households have successfully escaped poverty by improving land productivity and growing commercial crops (World Bank 2008). In Rajasthan and Andhra Pradesh of India, Krishna $(2004,2006)$ finds that livelihood diversification is the significant determinant for households in moving out of poverty. Nevertheless, this study does not resonate what Rigg (2006) argues that detaching the poor from land, and thus, agriculture is an effective pathway out of poverty. Bryceson (1996) observes deagrarianisation $^{2}$ in sub-Sahara Africa, where rural people have become increasingly less reliant on farming as a source of their livelihood. The deagrarianisation thesis partly holds true for Nepal. The share of agricultural employment (from 83 to $64 \%$ ) and farm income (from 61 to $28 \%$ ) has declined between 1996 and 2004. Also declining is the share of agriculture in the total GDP (CBS 2011).

For effective poverty alleviation, preventing households from falling into poverty is as important as escaping from poverty as mentioned earlier. In this study, important reasons reported to be associated with households that have slipped into poverty include loss of land, health costs, and social and cultural expenses. These reasons are similar to those explored by Kristjanson et al. (2010) in Kenya, and by Krishna (2006) and Krishna et al. (2006) in India and Uganda, respectively. These studies identify poor health, high medical costs, high interest debts and huge customary and religious expenses as major factors pushing households into impoverishment.

This paper concludes that the diversification of income sources tend to be a major reason behind households moving out of poverty as many other similar studies indicate. Nevertheless, what type of diversification strategy works well for many households remains an issue to be resolved. With caution, this study suggests that a combination of farming and foreign migration seems to be working quite well for many households in the Tarai region of Nepal. In another context, foreign migration is, however, not an element of diversification (Krishna et al. 2006; Kristjanson et al. 2010). Similarly, apart from social and cultural expenses, loss of land or loss of access to land stands as a main reason associated with falling into poverty. Access to land turns out to be an important factor for explaining both facets of poverty - escape from and descent into poverty. Krishna (2004) and Krishna et al. (2006) also identify land-related factors, land improvement and commercial farming, to name a few, but the authors do not extend such findings to advocate policies for land reform or at least tenure reform. This paper also suggests that land reform including tenure reform (terms and conditions of farming

2 Deagrarianisation is defined as 'a process of: (i) economic activity reorientation (livelihood), (ii) occupation adjustment (work activity) and (iii) spatial realignment of human settlement (residence) away from agrarian patterns. Overt and measurable manifestations of this process are as follows: a diminishing degree of rural household food and basic needs self-sufficiency, a decline in agricultural labour relative to non-agricultural labour in rural households, and in total national expenditure, a decrease in agricultural output per capita in the national economy relative to agriculture output, and a shrinking proportion of the total population residing in rural areas' (Bryceson 1996, p. 99). 
that favour tenants) is much likely to benefit many poor people since most of them are still attached to land and farming, largely on adverse terms (Sugden 2009). In generic terms, the socio-economic and cultural context matters a lot for devising effective anti-poverty strategies.

Acknowledgments I am grateful to the ANU Crawford School of Public Policy for providing funding for this research. Associate Professor John F McCarthy deserves special thanks for his intellectual and scholarly guidance throughout this study. I am indebted to Sita Magar and Mohan Timsina for assisting me during the fieldwork in Sunsari, Nepal. I am also grateful to my colleagues, Mandip Rai and Binod Chapagain, for their constructive comments. The usual disclaimer applies.

Open Access This chapter is distributed under the terms of the Creative Commons Attribution Noncommercial License, which permits any noncommercial use, distribution, and reproduction in any medium, provided the original author(s) and source are credited.

\section{References}

ADB (2009) Nepal: critical development constraints. Asian Development Bank, Manila

Adhikari J, Hobley M (2011) Everyone is leaving-who will sow our fields? The effects of migration from Khotang district to the Gulf and Malaysia. SDC, Kathmandu

Banerjee A, Iyer L (2005) History, institutions, and economic performance: the legacy of colonial land tenure systems in India. Am Econ Rev 95:1190-1213

Barrett CB, Marenya PP, McPeak J, Minten B, Murithi F, Oluoch-Kosura W, Place F, Randrianarisoa JC, Rasambainarivo J, Wangila J (2006) Welfare dynamics in rural Kenya and Madagascar. J Dev Stud 42:248-277

Barrett CB, Reardon T, Webb P (2001) Nonfarm income diversification and household livelihood strategies in rural Africa: concepts, dynamics, and policy implications. Food Policy 26:315-331

Bryceson DF (1996) Deagrarianization and rural employment in sub-Saharan Africa: a sectoral perspective. World Dev 24:97-111

Carter MR, Barrett CB (2006) The economics of poverty traps and persistent poverty: an assetbased approach. J Dev Stud 42:178-199

CBS (2011) Nepal living standard survey 2010/2011: statistical report, vols I and II. Central Bureau of Statistics (CBS), Kathmandu

Christiaensen LJ, Subbarao K (2005) Towards an understanding of household vulnerability in rural Kenya. J Afr Econ 14:520-558

Davis P, Baulch B (2011) Parallel realities: exploring poverty dynamics using mixed methods in rural Bangladesh. J Dev Stud 47:118-142

De Haas H (2005) International migration, remittances and development: myths and facts. Third World Q 26:1269-1284

De Weerdt J (2006) Moving out of poverty in Tanzania's Kagera region. Economic Development Initiatives, Bukoba

Ellis F (2000) Rural livelihoods and diversity in developing countries. Oxford University Press, Oxford

Flyvbjerg B (2002) Making social science matter: why social inquiry fails and how it can succeed again. Taylor \& Francis, UK

GON (2011) Economic survey: fiscal year 2010/11. Ministry of Finance, Government of Nepal (GoN), Kathmandu 
Krishna A (2004) Escaping poverty and becoming poor: who gains, who loses, and why? World Dev 32:121-136

Krishna A (2006) Pathways out of and into poverty in 36 villages of Andhra Pradesh, India. World Dev 34:271-288

Krishna A (2010) Who became poor, who escaped poverty, and why? Developing and using a retrospective methodology in five countries. J Polit Anal Manage 29:351-372

Krishna A, Lumonya D, Markiewicz M, Mugumya F, Kafuko A, Wegoye J (2006) Escaping poverty and becoming poor in 36 villages of Central and Western Uganda. J Dev Stud 42:346-370

Kristjanson P, Mango N, Krishna A, Radeny M, Johnson N (2010) Understanding poverty dynamics in Kenya. J Int Dev 22:978-996

Lawson D, McKay A, Okidi J (2006) Poverty persistence and transitions in Uganda: a combined qualitative and quantitative analysis. J Dev Stud 42:1225-1251

Lokshin M, Bontch-Osmolovski M, Glinskaya E (2007) Work-related migration and poverty reduction in Nepal. World Bank Policy Research Working Paper No 4231

Moser C, Felton A (2007) Intergenerational asset accumulation and poverty reduction in Guayaquil Ecuador (1978-2004). Reducing Glob Poverty Case Asset Accumulation 15-50 http://books.google.com.au/books?hl=en\&lr=lang_en\&id=wLo2k72-YGoC\&oi=fnd\&p $\mathrm{g}=\mathrm{PP} 1 \& \mathrm{dq}=$ Reducing + Global + Poverty + The + Case + for + Asset + Accumulation $\&$ ots $=$ aTcp02_q9u\&sig=qI6pjX564uLYYWiNc1GmQJxUo2E\#v=onepage \&q=Reducing $\% 20$ Global\%20Poverty\%20The\%20Case\%20for\%20Asset\%20Accumulation\&f=false

Mosse D, Gupta S, Shah V (2005) On the margins in the city: adivasi seasonal labour migration in western India. Econ Polit Wkly 40:3025-3038

Poertner E, Junginger M, Müller-Böker U (2011) Migration in far western Nepal. Critical Asian Stud 43:23-47

Quisumbing MAR (2007) Poverty transitions, shocks, and consumption in rural Bangladesh: preliminary results from a longitudinal household survey. Chronic Poverty Research Centre, Manchester

Ravallion M (2001) Growth, inequality and poverty: looking beyond averages. World Dev 29:1803-1815

Rigg J (2006) Land, farming, livelihoods, and poverty: rethinking the links in the rural South. World Dev 34:180-202

Sugden F (2009) Neo-liberalism, markets and class structures on the Nepali lowlands: the political economy of agrarian change. Geoforum 40:634-644

White H (2002) Combining quantitative and qualitative approaches in poverty analysis. World Dev 30:511-522

World Bank (2008) World development report 2008: agriculture for development. World Bank, Washington 